\title{
Effect of Synthetic Compounds on Performance of Wheat under High Temperature Stress Condition
}

\author{
Asheesh Chaurasiya ${ }^{1}$, Durgesh Singh ${ }^{1 *}$, Swaraj Kumar Dutta ${ }^{1}$, \\ Shiv Bahadur ${ }^{2}$ and Santosh Kumar Dubey ${ }^{1}$ \\ ${ }^{1}$ Department of Agronomy, BAU, Bhagalpur-813210, India \\ ${ }^{2}$ Department of Agronomy, NDUA\&T, Faizabad-224229, India \\ *Corresponding author
}

\section{Keywords \\ $\mathrm{KNO}_{3}, \mathrm{CaCl}_{2}$, \\ Glycinebetaine, Arginine, \\ Nutrient content and \\ uptake, Wheat yield and \\ economics}

Article Info

Accepted:

26 April 2018

Available Online:

10 May 2018

\section{A B S T R A C T}

A field experiment was carried out in experimental farm of Bihar Agricultural University, Bhagalpur during the rabi season of 2014-15 to test the effect of synthetic compounds on performance of wheat under high temperature stress condition. Treatments were laid out in split plot design with three replications. Two contrasting varieties of wheat, i.e. DBW-14 (timely sown) and K 307 (late sown) were kept in main plots. Each main plot was further sub-divided into fourteen subplots which received foliar spray of different synthetic compounds either at a fixed dose at booting or at anthesis stage or half the fixed dose at both booting and anthesis stage. The foliar spray were as follows: $\mathrm{M}_{1}-$ no spray, $\mathrm{M}_{2}-\mathrm{KNO}_{3}$ $(1.0 \%)$ at booting stage, $\mathrm{M}_{3}-\mathrm{KNO}_{3}(1.0 \%)$ at anthesis stage, $\mathrm{M}_{4}-\mathrm{KNO}_{3}(0.5 \%)$ both at booting and anthesis stage, $\mathrm{M}_{5^{-}} \mathrm{CaCl}_{2}(0.2 \%)$ at booting stage, $\mathrm{M}_{6^{-}} \mathrm{CaCl}_{2}(0.2 \%)$ at anthesis stage, $\mathrm{M}_{7^{-}} \mathrm{CaCl}_{2}(0.1 \%)$ both at booting and anthesis stage, $\mathrm{M}_{8^{-}}$Glycinebetaine $(100 \mathrm{mM})$ at booting stage, $\mathrm{M}_{9^{-}}$Glycinebetaine $(100 \mathrm{mM})$ at anthesis stage, $\mathrm{M}_{10^{-}}$ Glycinebetaine $(50 \mathrm{mM})$ both at booting and anthesis stage, $\mathrm{M}_{11^{-}}$Arginine $(2.5 \mathrm{mM})$ at booting stage, $\mathrm{M}_{12^{-}}$Arginine $(2.5 \mathrm{mM})$ at anthesis stage, $\mathrm{M}_{13^{-}}$Arginine $(1.25 \mathrm{mM})$ both at booting and anthesis stage and $\mathrm{M}_{14}$-spray of water both at heading and anthesis stage. Result shows that grain yield was increased significantly and maximized (36.96 and 31.23 qha ${ }^{-1}$ for $\mathrm{V}_{1}$ and $\mathrm{V}_{2}$ respectively) when the crop received foliar spray of $\mathrm{KNO}_{3}$ at the rate of $0.5 \%$ both during booting and anthesis stage over no foliar spray. The corresponding values with the foliar spray of $\mathrm{CaCl}_{2}$ showed same trend like $\mathrm{KNO}_{3}$ and were found to be statistically at par. Economic analysis revealed that the foliar spray of $\mathrm{KNO}_{3}$ at the rate of $0.5 \%$ both during booting and anthesis in DBW-14 significantly increased and maximized B: C ratio (1.9) over control but did not respond significantly in $\mathrm{K} 307$. Thus, the study suggests that foliar spray of $\mathrm{KNO}_{3}$ at the rate of $0.5 \%$ both during booting and anthesis in a short duration variety like DBW-14 is beneficial to mitigate the ill effects of high temperature stress and enhance the yield to a profitable limit.

\section{Introduction}

Wheat (Triticum aestivum L.) $2 \mathrm{n}=42$ belongs to family Poaceae, mostly cultivated in temperate region as well as in tropical and subtropical climate with moderate success. In India, wheat plays an important role towards food security of the nation. Cultivation of 
wheat has been the symbol of green revolution and self-sufficiency in food grain production of the nation. According to FAO estimate, world would require around 840 million tonnes of wheat and India require about 140 million tonnes by the year 2050 .

Environment is continuously changing over the past years due to human-induced activity and extreme climate events. Heat waves, droughts and floods are become a common phenomenon as a result of climate change (IPCC, 2012). Global climate models predict an increase in mean ambient temperatures between 1.8 and $5.8^{\circ} \mathrm{C}$ by the end of this century (IPCC, 2007). Agricultural production and global food security is directly affected by global warming (Ainsworth and Ort, 2010). Sowing of wheat often gets delayed under rice-wheat cropping system due to late harvesting of paddy (Prasad et al., 2005). Due to late sowing of wheat, anthesis and grain filling period faces increased temperature (more than $20^{\circ} \mathrm{C}$ ) (Tewolde et al., 2006). High temperature stress is a major environmental stress that limits crop growth, metabolism and productivity, because temperature controls the rate of plant metabolic processes that ultimately influence the production of biomass, spikelets and grains (Hay and Walker, 1989). Previous global food assessments have shown that these negative effects are particularly exacerbated in tropical regions (Fischer et al., 2005). Presently, Indian lowlands are the source of approximately $15 \%$ of global wheat production but it is anticipated that climate change will transform these into a heat stressed, short season production environment (Bita and Gerats, 2013).Wheat cultivation faces numerous challenges of terminal heat stress, which is a major constraint that limiting the wheat production. High temperature stress during reproductive phase of crop is termed as terminal heat stress. Wheat crop requires $19^{\circ} \mathrm{C}$ to $22^{\circ} \mathrm{C}$ temperature during setting and filling of grain (Porter and Gawith, 1999). The threshold temperature i.e. the value of daily mean temperature at which a detectable reduction in growth begins is $26^{\circ} \mathrm{C}$ for wheat at post anthesis stage (Stone and Nicolas, 1994). During the grain filling period, heat stress can accelerate leaf senescence and affect final grain weight by shortening the duration of grain filling (Dias and Lidon, 2009).

Lobell et al., (2005) reported that wheat yield in Mexico decreased by $10 \%$ for every $1{ }^{\circ} \mathrm{C}$ increase in night temperature and grain yield showed a strong negative correlation with increasing minimum temperature (Corbellini et al., 1997 and Stone and Nicolas, 1995). stated that two typical heat stresses are common during wheat grain filling i.e. "Heat shock" which is characterized by sudden extreme high temperatures $\left(>32^{\circ} \mathrm{C}\right)$ for a short duration (3-5 days) while, "chronic heat stress" consists of moderately high maximum temperatures $\left(20-30^{0} \mathrm{C}\right)$ for a longer duration. High temperature during reproductive phase of wheat resulted, decline in photosynthesis, leaf area, water-use efficiency and decrease shoot and grain mass, kernels weight and sugar content (Shah and Paulsen, 2003). Wheat is much affected by relatively short periods (3-5 days) of heat stress in terms of yields and quality, especially when occurring during grain filling stage (Wardlaw et al., 2002).

The North Indian states such as Uttar Pradesh, Punjab, Haryana, Uttarakhand and Himachal Pradesh are some of the major wheat producing states where the crop is more vulnerable at a $1{ }^{\circ} \mathrm{C}$ rise in temperature resulting in reduction of wheat yield (Singh et al., 2011) and according to a report of Ministry of Agriculture, GOI, $1^{0} \mathrm{C}$ rise temperature during the growing season can result in 3-7\% decrease in grain yield. Loss in yield of wheat due to elevated temperature is estimated in the vicinity of 50 percent by 2050 
(IFPRI 2011). This yield loss will threaten the food security of at least 1.6 billion people in South Asia.

The yield loss of late sown wheat facing high temperature stress can be improved by exogenous application of many synthetic compounds. These synthetic compounds are inorganic salts like potassium nitrate, calcium chloride, glycine betaine and arginine. Several studied says that these compounds mitigate the ill effects of high temperature stress in plants through various mechanisms like preventing the degradation of chlorophyll, reducing electrolytic leakage and help to maintain or sometime increase the grain yield of crop. The main function of these compounds is as follow;

$\mathrm{KNO}_{3}$ - Potassium $(\mathrm{K}+)$ has substantial effect on enzyme activation, protein synthesis, photosynthesis, stomatal movement and water-relation (turgor regulation and osmotic adjustment) in plants (Marschner, 1995). Increased application of $\mathrm{K}+$ has been shown to enhance photosynthetic rate, growth, yield and drought resistance in different crops under abiotic stress conditions (Egilla et al., 2001). $\mathrm{CaCl}_{2}$ - Under heat stress, $\mathrm{Ca}^{2+}$ can maintenance of antioxidant activity in some cool season grasses (Jiang and Haung, 2001). Calcium application in the form of $\mathrm{CaCl}_{2}$ increased the malondialdehyde (MDA) content (lipid per oxidation product) and stimulated the activities of SOD and catalase, which could be the reason for the induction of heat tolerance (kolupaev et al., 2005). Glycinebetaine - Glycinebetaine is the low molecular weight organic compounds have been successfully applied to induce high temperature tolerance in plants.Numerus reports are also available to show beneficial effects of some compounds like potassium nitrate (Sarkar and Bandopadhyay, 1991; Sarkar and Tripathy, 1994), calcium chloride (Tan et al., 2011), glyceinebetaine (Rhodes and Hanson, 1993, Ashraf et al., 2007) and arginine (Hassanein et al., 2013) in many crops including wheat when applied exogenously under abiotic stresses like high temperature and drought. The main functions of these sprayed compounds are protection of chlorophyll, detoxification of reactive oxygen species, maintenance of favorable balance of water and photosynthesis in plants under stressful condition.

So, this experiment was conducted to test the efficacy of these synthetic compounds for improving grain yield by enhancing tolerance capacity of the crop against high temperature stress. Our mainfocus is reducing the impact of heat stress during reproductive and grain filling stages of wheat and develop a strategy to improve tolerance in late sown wheat.

\section{Materials and Methods}

\section{Experimental site}

A field experiment was conducted during rabi season 2014-15 at Crop Research Farm, Department of Agronomy, Bihar Agricultural University, Bhagalpur, Bihar. The geographical location of Bhagalpur comes under the Middle Gangetic plain region of Agro-climatic Zone III (A) in Bihar. It located between $25^{\circ} 50^{\prime} \quad \mathrm{N}$ latitude and $87^{\circ} 19^{\prime}$ longitude at an altitude of 52.73 meter above mean sea-level. The soil at the experimental site was sandy loam with $\mathrm{pH}$ 6.92, bulk density $1.49 \mathrm{~g} \mathrm{~cm}^{-3}$, organic carbon $0.49 \%$ and having $125.44,18.05$ and $118.95 \mathrm{~kg} \mathrm{ha}^{-1} \mathrm{~N}$ : P: $\mathrm{K}$ respectively.

\section{Climatic conditions of site}

Climate of Sabour, Bhagalpur is sub-tropical, hot desiccating summer, cold winter and moderate rainfall. December and January are usually the coldest month where the mean temperature normally fall as low as $8.8^{\circ} \mathrm{C}$ 
whereas; May and June are the hottest months, having the maximum average temperature of $36.1^{\circ} \mathrm{C}$. The average annual rainfall is about $1207 \mathrm{~mm}$ (10 years' average) precipitating mostly between middle of June to middle of October.

\section{Weather parameters during the experimental period}

During experiment the maximum temperature varied from $18.1-32.2^{\circ} \mathrm{C}, \quad$ minimum temperature ranged from $5.8-20.5^{\circ} \mathrm{C}$ and mean temperature period varied from 11.95$25.95^{\circ} \mathrm{C}$. So, meteorological data reveals that the wheat crop faced high temperature stress (beyond $20^{\circ} \mathrm{C}$ ) from February $2^{\text {nd }}$ week onwards, which coincides with its grain filling stage. The crop received a total rainfall of 9.48 mm from December, 2014 to March 2015.

\section{Experimental details}

The experiment was laid out in the split plot design with three replications and size of experimental plot was $10 \mathrm{~m}^{2}$. Sowing date was December 29, 2014 which considered as late sown irrigated condition for the region, with spacing $20 \mathrm{~cm}$ (row to row) and fertilizer dose was 80: 40: 40: $\left(\mathrm{N}: \mathrm{P}_{2} \mathrm{O}_{5}: \mathrm{K}_{2} \mathrm{O} \mathrm{Kg} / \mathrm{ha}\right.$ ). In this experiment two contrasting wheat varieties had been taken namely, DBW-14 (V1) and K307 (V2). Variety DBW-14 is recommended for late sown irrigated conditions. The optimum sowing time of this variety is between $10^{\text {th }}$ December to last week of December with 110-115 days' maturity period, having average yielding potential is about $30-40 \mathrm{q} \mathrm{ha}^{-1}$. Second variety K-307 is recommended for timely sown irrigated condition. The optimum sowing time of this variety is 15 to $30^{\text {th }}$ November with $125-130$ days' maturity period, having average yielding ability is about 40-50 $\mathrm{qha}^{-1}$. Different chemical compounds are sprayed in different quantity and on different growth stage of wheat for reducing the stress of high temperature. The treatments were; $\mathrm{M}_{1}$ - control plot, $\mathrm{M}_{2^{-}} \mathrm{KNO}_{3}$ at booting stage $(1.0 \%), \mathrm{M}_{3}-$ $\mathrm{KNO}_{3}$ at anthesis stage $(1.0 \%)$ and $\mathrm{M}_{4}-\mathrm{KNO}_{3}$ $(0.5 \%)$ both at booting and anthesis stage, $\mathrm{M}_{5-}$ $\mathrm{CaCl}_{2}$ at booting stage $(0.2 \%), \mathrm{M}_{6^{-}} \mathrm{CaCl}_{2}$ at anthesis stage $(0.2 \%)$ and $\mathrm{M}_{7-} \mathrm{CaCl}_{2}(0.1 \%)$ both at booting and anthesis stage, $\mathrm{M}_{8^{-}}$ Gycinebetain at booting stage $(100 \mathrm{mM}), \mathrm{M}_{9}$ Glycine betain at anthesis stage $(100 \mathrm{mM})$ and $\mathrm{M}_{10^{-}}$Glycinebetain $(50 \mathrm{mM})$ both at booting and anthesis stage, $\mathrm{M}_{11^{-}}$arginine $(2.5 \mathrm{mM})$ at booting stage, $\mathrm{M}_{12}$ - arginine atanthesis stage, $\mathrm{M}_{13^{-}}$arginine $(1.25 \mathrm{mM})$ both at booting and anthesis stage and $\mathrm{M}_{14^{-}}$spray of water at both heading and anthesis stage.

\section{Results and Discussion}

Effect of the synthetic compounds on nutrient content and uptake

Application of synthetic compounds at different doses and stage does not affected significantly nitrogen and phosphorus (\%) content in wheat grain and straw while, potassium content (\%) in wheat grain and straw was found to be affected significantly (Table 2). Maximum potassium content (\%) was recorded with the application of $\left(\mathrm{M}_{4}\right)$ $\mathrm{KNO}_{3} @ 0.5 \%$ at booting and anthesis stage in wheat grain $(0.29 \%)$ and straw (1.28\%), followed by $\mathrm{KNO}_{3} @ 1 \%$ at anthesis stage in wheat grain $(0.28 \%)$ and straw (1.26\%). Same pattern was observed in nutrient uptake (Table 3) because uptake is totally based on nutrient content and yield of crop. Between varieties there is no significant difference was observed while among treatments $\mathrm{K}$ uptake was affected significantly by the application of synthetic compounds. Maximum N uptake $(68.66 \mathrm{~kg}$ $\left.\mathrm{ha}^{-1}\right)$ and P uptake (17.80 $\left.\mathrm{kg} \mathrm{ha}^{-1}\right)$ was found in variety DBW-14 but maximum $\mathrm{K}$ content was recorded variety $\mathrm{K}-307\left(72.67 \mathrm{~kg} \mathrm{ha}^{-1}\right)$. In case sub plot maximum $\mathrm{N}$ uptake $(73.48 \mathrm{~kg}$ $\left.\mathrm{ha}^{-1}\right)$, P uptake (19.28 $\left.\mathrm{kg} \mathrm{ha}^{-1}\right)$ and $\mathrm{K}$ uptake 
(75.46 kg ha $\left.{ }^{-1}\right)$ was recorded with application of $\left(\mathrm{M}_{4}\right) \mathrm{KNO}_{3} @ 0.5 \%$ at booting and anthesis stage. Application of synthetic compounds provides protection against high temperature stress by several action in plant body. Literature says that these compounds mitigate the ill effects of high temperature stress in plants through various mechanisms like preventing the degradation of chlorophyll, reducing electrolytic leakage from cells etc.

Foliar spray of $\mathrm{KNO}_{3}$ helps in protecting the photosynthetic apparatus of flag leaf throughout the anthesis and post anthesis period, which is considered to be the principal contributory organ for the supply of photosynthates to the developing grain (Borrill et al., 2015). According to Wahid et al., (2007) photosynthesis is the most sensitive process to elevated temperature and it affects grain yield of wheat (Al-Khatib and Paulsen, 1999). The effect of high temperature during anthesis and grain filling period may disrupt the structure and function of chloroplast and reduces chlorophyll content (Xu et al., 1995), nutrient content and uptake by plants. It has also has been shows that exogenous $\mathrm{Ca}^{++}$ increased heat tolerance in several plants, which might be associative with high errant oxidative enzyme activities and reduced lipid peroxidation of cell membranes (Wang et al., 2009). The reason behind inclusion of the subplot treatments with glycinebetaine (Agboma et al., 1997) and arginine (Hassanein et al., 2008) is their protective rolesin plants against high temperature stress.

\section{Effect of the synthetic compounds on yields of wheat crop}

Grain yield (Table 4) of late sown wheat, facing high temperature stress from anthesis onwards, increased significantly and maximized (34.10 $\left.\mathrm{qha}^{-1}\right)$ over control (30.72 q $\mathrm{ha}^{-1}$ ) when the crop was sprayed with $0.5 \%$ $\mathrm{KNO}_{3}$ both at booting and anthesis stage $\left(\mathrm{M}_{4}\right)$ and was found to be at par with those obtained with $\mathrm{M}_{3}, \mathrm{M}_{7}$ and $\mathrm{M}_{6}$ receiving single foliar spray of $1 \% \mathrm{KNO}_{3}$ at anthesis (33.58 q ha-1), two foliar sprays of $0.1 \% \mathrm{Cacl}_{2}$ both at booting and anthesis (33.97 $\left.\mathrm{q} \mathrm{ha}^{-1}\right)$ and a single foliar spray of $0.2 \% \mathrm{CaCl}_{2}$ at anthesis $(33.58 \mathrm{q}$ $\left.\mathrm{ha}^{-1}\right)$, respectively. Across the two varieties, an increment of $10.99 \%, 10.59 \%, 9.45 \%$ and $9.31 \%$ in grain yield was observed in $\mathrm{M}_{4}, \mathrm{M}_{7}$, $\mathrm{M}_{3}$ and $\mathrm{M}_{6}$, respectively over control.

However, a varietal difference was observed between DBW-14 and K-307 with respect to grain yield when sprayed with different synthetic compounds. The quantum response in grain yield was found to be more pronounced in DBW-14 than in K307.In DBW 14, $\mathrm{M}_{4}$ treatment produced the highest yield (36.96qha ${ }^{-1}$ ) which was at par with $\mathrm{M}_{3}$ (36.52q ha $\left.{ }^{-1}\right), \mathrm{M}_{7}\left(36.22 \mathrm{q} \mathrm{ha}^{-1}\right)$ and $\mathrm{M}_{6}(36.20$ $\mathrm{qha}^{-1}$ ) and were $17.28 \%, 15.88 \%, 14.93 \%$ and $14.88 \%$ higher over the yield of $\mathrm{M}_{1}$ /control (31.51 q ha ${ }^{-1}$ ), respectively. But in K-307, highest yield was obtained in $\mathrm{M}_{7}\left(31.73 \mathrm{q} \mathrm{ha}^{-}\right.$ 1) which was followed by $\mathrm{M}_{4}\left(31.23 \mathrm{q} \mathrm{ha}^{-1}\right)$ and were $6.03 \%$ and $4.36 \%$ higher over the yield ofM 1 /control (29.92 $\left.\mathrm{q} \mathrm{ha}^{-1}\right)$ respectively.

The maximum straw yield was recorded in variety K-307 (52.75 q ha $\left.{ }^{-1}\right)$ followed by DBW-14 (47.69 $\left.\mathrm{qha}^{-1}\right)$ while, by the application of synthetic compounds maximum straw yield was recorded in $\mathrm{M}_{6}$ (51.61qha ${ }^{-1}$ ) treatment which was statistically at par with $\mathrm{M}_{4}$ followed by $\mathrm{M}_{7}$ and $\mathrm{M}_{3}$ treatment. The straw yield in $\mathrm{M}_{6}$ treatment recorded $6.89 \%$ increase over $\mathrm{M}_{1}$ (control) treatment. As the grain and straw yields responded similarly to the foliar spray of synthetic compounds, the harvest index was highest in variety DBW 14 $(41.81 \%)$. Among the sub plot treatments, $\mathrm{M}_{4}$ recorded highest harvest index $(44.34 \%)$ which was $10.95 \%$ higher over $\mathrm{M}_{1}$ (control) treatment followed by $\mathrm{M}_{3}, \mathrm{M}_{7}$ and $\mathrm{M}_{6}$ treatments. On an average, $\mathrm{M}_{4}$ treatments had the highest HI which was $40.06 \%$ higher over $\mathrm{M}_{1}$ treatment. 
Table.1 Temperature variability at different phonological stage of wheat during rabi season of 2014-15

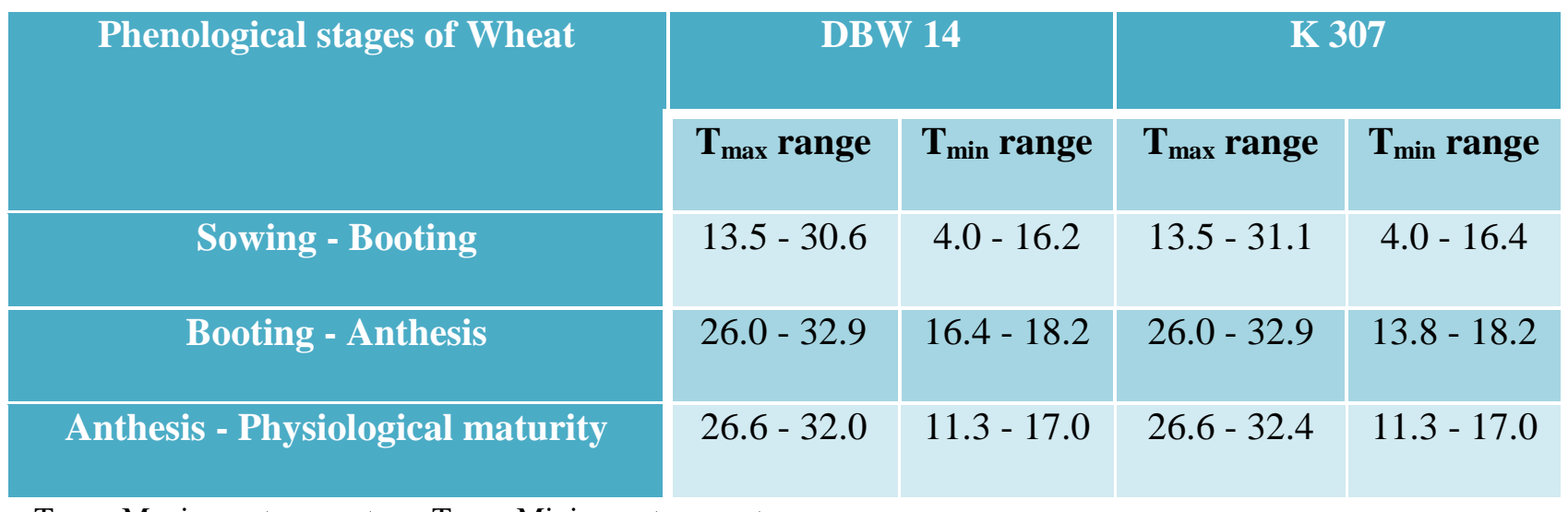

$\mathrm{T}_{\max }-$ Maximum temperature, $\mathrm{T}_{\min }-$ Minimum temperature

Table.2 Effect of foliar spray of synthetic compounds on N, P and K content of wheat (grain and straw)

\begin{tabular}{|c|c|c|c|c|c|c|}
\hline \multirow[t]{2}{*}{ Treatments } & \multicolumn{2}{|c|}{$\% \mathbf{N}$} & \multicolumn{2}{|c|}{$\% \mathbf{P}$} & \multicolumn{2}{|c|}{$\% \mathrm{~K}$} \\
\hline & Grain & Straw & Grain & Straw & Grain & Straw \\
\hline \multicolumn{7}{|l|}{ Cultivars } \\
\hline V1- DBW 14 & 1.35 & 0.47 & 0.45 & 0.05 & 0.25 & 1.20 \\
\hline V2-K 307 & 1.37 & 0.45 & 0.48 & 0.04 & 0.26 & 1.23 \\
\hline $\operatorname{SEm}( \pm)$ & 0.02 & 0.007 & 0.01 & 0.01 & 0.01 & 0.06 \\
\hline $\mathrm{CD}(\mathrm{P}=0.05)$ & NS & NS & NS & NS & NS & NS \\
\hline \multicolumn{7}{|l|}{ Sprayed compound } \\
\hline$M_{1}$ - No spray (control) & 1.36 & 0.48 & 0.44 & 0.04 & 0.26 & 1.21 \\
\hline $\mathrm{M}_{2}-\mathrm{KNO}_{3}(1 \%) \mathrm{B}$ & 1.32 & 0.45 & 0.44 & 0.05 & 0.28 & 1.22 \\
\hline $\mathrm{M}_{3}-\mathrm{KNO}_{3}(\mathbf{1 \%}) \mathrm{A}$ & 1.35 & 0.44 & 0.46 & 0.04 & 0.28 & 1.26 \\
\hline $\mathrm{M}_{4}-\mathrm{KNO}_{3}(0.5 \%) \mathrm{B}+\mathrm{A}$ & 1.43 & 0.48 & 0.49 & 0.05 & 0.29 & 1.28 \\
\hline $\mathrm{M}_{5}-\mathrm{CaCl}_{2}(0.2 \%) \mathrm{B}$ & 1.33 & 0.44 & 0.48 & 0.04 & 0.26 & 1.22 \\
\hline $\mathrm{M}_{6}-\mathrm{CaCl}_{2}(0.2 \%) \mathrm{A}$ & 1.36 & 0.42 & 0.47 & 0.04 & 0.23 & 1.17 \\
\hline $\mathrm{M}_{7}-\mathrm{CaCl}_{2}(0.1 \%) \mathrm{B}+\mathrm{A}$ & 1.35 & 0.41 & 0.49 & 0.05 & 0.26 & 1.20 \\
\hline $\mathrm{M}_{8-} \mathrm{GB}(100 \mathrm{mM}) \mathrm{B}$ & 1.37 & 0.49 & 0.47 & 0.05 & 0.27 & 1.24 \\
\hline $\mathrm{Mg}_{9}$-GB $(100 \mathrm{mM}) \mathrm{A}$ & 1.38 & 0.44 & 0.46 & 0.04 & 0.22 & 1.18 \\
\hline $\mathrm{M}_{10^{-}} \mathrm{GB}(50 \mathrm{mM}) \mathrm{B}+\mathrm{A}$ & 1.39 & 0.49 & 0.48 & 0.04 & 0.23 & 1.21 \\
\hline $\mathrm{M}_{11}$ - Arginine $(2.50 \mathrm{mM}) \mathrm{B}$ & 1.41 & 0.44 & 0.45 & 0.04 & 0.28 & 1.22 \\
\hline $\mathrm{M}_{12^{2}}$ Arginine $(2.50 \mathrm{mM}) \mathrm{A}$ & 1.34 & 0.48 & 0.46 & 0.05 & 0.27 & 1.17 \\
\hline $\begin{array}{l}\mathrm{M}_{13-} \text {-Arginine } \\
\mathrm{B}+\mathrm{A}\end{array}$ & 1.38 & 0.47 & 0.45 & 0.05 & 0.23 & 1.23 \\
\hline $\mathbf{M}_{14}$-Water spray $(\mathbf{H}+\mathbf{A})$ & 1.33 & 0.50 & 0.47 & 0.05 & 0.25 & 1.21 \\
\hline $\operatorname{SEm}( \pm)$ & - & - & - & - & 0.04 & 0.06 \\
\hline $\mathrm{CD}(\mathrm{P}=0.05)$ & NS & NS & NS & NS & 0.01 & 0.02 \\
\hline
\end{tabular}


Table.3 Effect of foliar spray of synthetic compounds on N, P and K uptake of wheat crop

\begin{tabular}{|c|c|c|c|c|c|c|c|c|c|}
\hline \multirow[t]{2}{*}{ Treatments } & \multicolumn{2}{|c|}{ N uptake } & \multirow{2}{*}{$\begin{array}{c}\text { Total N } \\
\text { uptake } \\
\left(\mathrm{Kg} \mathrm{ha}^{-1}\right)\end{array}$} & \multicolumn{2}{|c|}{ P uptake } & \multirow{2}{*}{$\begin{array}{c}\text { Total P } \\
\text { uptake } \\
\left(\mathrm{Kg} \mathrm{ha}^{-1}\right)\end{array}$} & \multicolumn{2}{|c|}{ K uptake } & \multirow{2}{*}{$\begin{array}{c}\text { Total K } \\
\text { uptake } \\
\left(\mathrm{Kg} \mathrm{ha}^{-1}\right)\end{array}$} \\
\hline & Grain & Straw & & Grain & Straw & & Grain & Straw & \\
\hline \multicolumn{10}{|l|}{ Cultivars } \\
\hline DBW 14 & 46.25 & 22.41 & 68.66 & 15.42 & 2.38 & 17.8 & 8.57 & 57.23 & 65.8 \\
\hline K 307 & 41.07 & 23.74 & 64.80 & 14.39 & 2.11 & 16.5 & 7.79 & 64.88 & 72.67 \\
\hline $\operatorname{SEm}( \pm)$ & 0.02 & 0.007 & - & 0.01 & 0.01 & - & 0.01 & 0.06 & - \\
\hline $\mathrm{CD}(\mathrm{P}=0.05)$ & NS & NS & - & NS & NS & - & NS & NS & - \\
\hline \multicolumn{10}{|l|}{ Sprayed compounds } \\
\hline $\mathrm{M}_{1}$ - No spray (control) & 41.78 & 23.17 & 64.95 & 13.52 & 1.93 & 15.45 & 7.99 & 58.41 & 66.39 \\
\hline $\mathrm{M}_{2}-\mathrm{KNO}_{3}(1 \%) \mathrm{B}$ & 42.31 & 22.73 & 65.04 & 14.10 & 2.53 & 16.63 & 8.97 & 61.63 & 70.61 \\
\hline $\mathrm{M}_{3}-\mathrm{KNO}_{3}(1 \%) \mathrm{A}$ & 45.33 & 22.57 & 67.90 & 15.45 & 2.05 & 17.50 & 9.74 & 64.63 & 74.36 \\
\hline $\mathrm{M}_{4}-\mathrm{KNO}_{3}(0.5 \%) \mathrm{B}+\mathrm{A}$ & 48.76 & 24.72 & 73.48 & 16.71 & 2.57 & 19.28 & 9.55 & 65.91 & 75.46 \\
\hline $\mathrm{M}_{5}-\mathrm{CaCl}_{2}(0.2 \%) \mathrm{B}$ & 41.93 & 21.42 & 63.36 & 15.13 & 1.95 & 17.08 & 8.20 & 59.40 & 67.60 \\
\hline $\mathrm{M}_{6}-\mathrm{CaCl}_{2}(0.2 \%) \mathrm{A}$ & 45.72 & 21.68 & 67.40 & 15.80 & 2.06 & 17.87 & 7.73 & 60.38 & 68.12 \\
\hline $\mathrm{M}_{7}-\mathrm{CaCl}_{2}(0.1 \%) \mathrm{B}+\mathrm{A}$ & 45.86 & 21.05 & 66.90 & 16.65 & 2.57 & 19.21 & 8.83 & 61.60 & 70.43 \\
\hline $\mathrm{M}_{8-} \mathrm{GB}(100 \mathrm{mM}) \mathrm{B}$ & 42.13 & 24.61 & 66.74 & 14.45 & 2.51 & 16.96 & 8.30 & 62.29 & 70.59 \\
\hline $\mathrm{M}_{9}-\mathrm{GB}(100 \mathrm{mM}) \mathrm{A}$ & 43.35 & 22.18 & 65.52 & 14.45 & 2.02 & 16.46 & 6.91 & 59.47 & 66.38 \\
\hline $\mathrm{M}_{10^{-}} \mathrm{GB}(50 \mathrm{mM}) \mathrm{B}+\mathrm{A}$ & 43.98 & 24.85 & 68.83 & 15.19 & 2.03 & 17.22 & 7.28 & 61.36 & 68.64 \\
\hline $\mathrm{M}_{11}$ - Arginine $(2.50 \mathrm{mM}) \mathrm{B}$ & 43.70 & 22.24 & 65.93 & 13.95 & 2.02 & 15.97 & 8.68 & 61.66 & 70.34 \\
\hline $\mathrm{M}_{12^{-}}$Arginine $(2.50 \mathrm{mM}) \mathrm{A}$ & 42.56 & 24.23 & 66.78 & 14.61 & 2.52 & 17.13 & 8.58 & 59.05 & 67.63 \\
\hline $\begin{array}{l}\mathrm{M}_{13} \text {-Arginine } \\
\mathrm{B}+\mathrm{A}\end{array}$ & 44.55 & 23.25 & 67.79 & 14.53 & 2.47 & 17.00 & 7.42 & 60.84 & 68.26 \\
\hline $\mathbf{M}_{14}-$ Water spray $(\mathbf{H}+\mathbf{A})$ & 41.56 & 24.04 & 65.60 & 14.69 & 2.40 & 17.09 & 7.81 & 58.18 & 65.99 \\
\hline $\operatorname{SEm}( \pm)$ & - & - & - & - & - & - & 0.04 & 0.06 & - \\
\hline $\mathrm{CD}(\mathrm{P}=0.05)$ & NS & NS & - & NS & NS & - & 0.01 & 0.02 & - \\
\hline
\end{tabular}


Table.4 Effect of foliar spray of synthetic compounds on yields of wheat and economics of different treatments

\begin{tabular}{|c|c|c|c|c|c|c|c|}
\hline Treatment & $\begin{array}{l}\text { Grain } \\
\text { Yield } \\
\left(\mathbf{q} \mathbf{h a}^{-1}\right)\end{array}$ & $\begin{array}{c}\text { Straw } \\
\text { yield } \\
\left(\mathbf{q} \mathbf{h a}^{-1}\right)\end{array}$ & $\begin{array}{c}\text { Harvest } \\
\text { Index } \\
(\%)\end{array}$ & $\begin{array}{c}\text { Cost of } \\
\text { cultivation } \\
\left(\square \mathbf{h a}^{-1}\right)\end{array}$ & $\begin{array}{c}\text { Gross } \\
\text { return } \\
\left(\square \mathbf{h a}^{-1}\right)\end{array}$ & $\begin{array}{c}\text { Net } \\
\text { return } \\
\left(\square \text { ha' }^{-1}\right)\end{array}$ & $\begin{array}{c}\text { B:C } \\
\text { Ratio }\end{array}$ \\
\hline \multicolumn{8}{|l|}{ Cultivars } \\
\hline $\mathrm{V}_{1}-\mathrm{DBW} 14$ & 34.26 & 47.69 & 41.81 & 27659 & 47960.34 & 20301.7 & 1.75 \\
\hline $\mathrm{V}_{2}-\mathrm{K} 307$ & 29.98 & 52.75 & 36.26 & 27658 & 41966.64 & 14308 & 1.54 \\
\hline $\operatorname{SEm}( \pm)$ & 1.56 & 0.48 & 0.38 & - & - & - & - \\
\hline $\mathrm{CD}(\mathrm{P}=0.05)$ & 0.26 & 2.89 & 2.36 & - & - & - & - \\
\hline \multicolumn{8}{|l|}{ Sprayed compounds } \\
\hline$M_{1}$ - No spray (control) & 30.72 & 48.27 & 38.94 & 25705 & 43005 & 17301 & 1.67 \\
\hline $\mathrm{M}_{2}-\mathrm{KNO}_{3}(1 \%) \mathrm{B}$ & 32.05 & 50.52 & 38.82 & 26905 & 44867 & 17962 & 1.67 \\
\hline $\mathrm{M}_{3}-\mathrm{KNO}_{3}(1 \%) \mathrm{A}$ & 33.58 & 51.29 & 39.63 & 26905 & 47010 & 20105 & 1.75 \\
\hline $\mathrm{M}_{4}-\mathrm{KNO}_{3}(0.5 \%) \mathrm{B}+\mathrm{A}$ & 34.10 & 51.49 & 40.06 & 27305 & 47733 & 20428 & 1.75 \\
\hline $\mathrm{M}_{5}-\mathrm{CaCl}_{2}(0.2 \%) \mathrm{B}$ & 31.53 & 48.69 & 39.31 & 29113 & 44135 & 15022 & 1.60 \\
\hline $\mathrm{M}_{6}-\mathrm{CaCl}_{2}(0.2 \%) \mathrm{A}$ & 33.62 & 51.61 & 39.50 & 29113 & 47071 & 17958 & 1.71 \\
\hline $\mathrm{M}_{7}-\mathrm{CaCl}_{2}(0.1 \%) \mathrm{B}+\mathrm{A}$ & 33.97 & 51.33 & 39.93 & 29513 & 47564 & 18051 & 1.70 \\
\hline $\mathrm{M}_{8-} \mathrm{GB}(100 \mathrm{mM}) \mathrm{B}$ & 30.75 & 50.23 & 37.93 & 27705 & 43048 & 15343 & 1.55 \\
\hline $\mathrm{M}_{9}-\mathrm{GB}(100 \mathrm{mM}) \mathrm{A}$ & 31.41 & 50.40 & 38.41 & 27705 & 43974 & 16269 & 1.59 \\
\hline $\mathrm{M}_{10^{-}} \mathrm{GB}(50 \mathrm{mM}) \mathrm{B}+\mathrm{A}$ & 31.64 & 50.71 & 38.41 & 28105 & 44292 & 16187 & 1.58 \\
\hline $\mathrm{M}_{11}$ - Arginine $(2.50 \mathrm{mM}) \mathrm{B}$ & 30.99 & 50.54 & 37.97 & 27414 & 43384 & 15970 & 1.58 \\
\hline $\mathrm{M}_{12}$-Arginine $(2.50 \mathrm{mM}) \mathrm{A}$ & 31.76 & 50.47 & 38.63 & 27414 & 44462 & 17048 & 1.62 \\
\hline $\mathrm{M}_{13}$-Arginine $(1.25 \mathrm{mM}) \mathrm{B}+\mathrm{A}$ & 32.28 & 49.46 & 39.55 & 27814 & 45190 & 17376 & 1.62 \\
\hline $\mathbf{M}_{14}$-Water spray $(\mathbf{H}+\mathbf{A})$ & 31.25 & 48.08 & 39.40 & 26505 & 43755 & 17250 & 1.65 \\
\hline $\operatorname{SEm}( \pm)$ & 1.80 & - & - & - & - & - & \\
\hline $\mathrm{CD}(\mathrm{P}=\mathbf{0 . 0 5})$ & 0.63 & NS & NS & - & - & - & - \\
\hline Interaction VxM & 2.54 & NS & 2.79 & - & - & - & - \\
\hline
\end{tabular}

$\mathrm{B}=$ Booting, $\mathrm{A}=$ Anthesis, $\mathrm{H}=$ Heading stage, $\mathrm{SEm}( \pm)=$ Standard error of mean, $\mathrm{CD}=$ Critical difference, $\mathrm{NS}=$ Non-significant, $\mathrm{GB}=\mathrm{Glycinebetain}, \mathrm{KNO}_{3}=$ Potassium nitrate, $\mathrm{CaCl}_{2}=\mathrm{Calcium}$ chloride, $\mathrm{B}: \mathrm{C}$ ratio $=$ Benefit: Cost ratio 
Fig.1 Temperature variation during crop period (anthesis to grain filling stage)

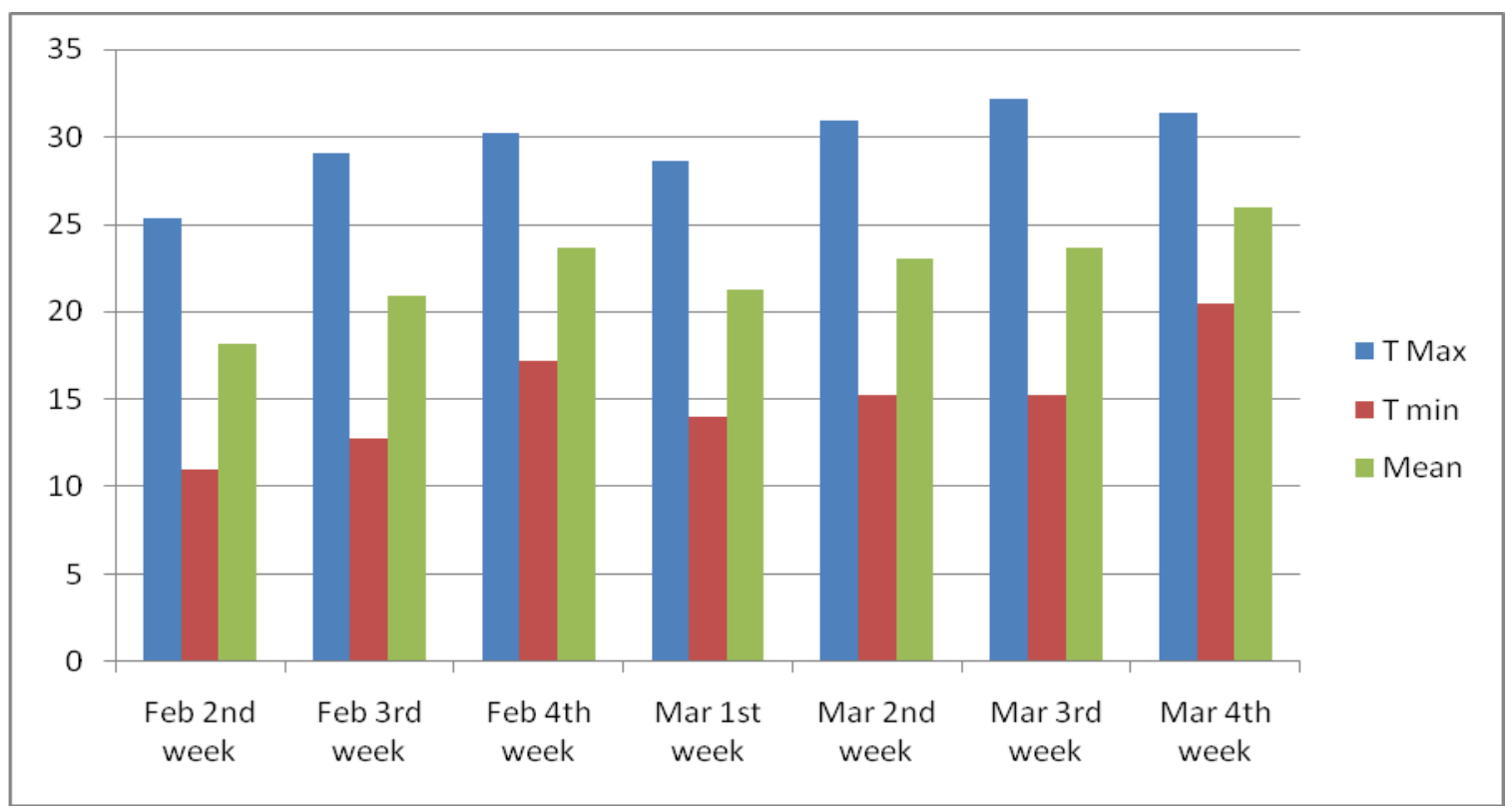

This suggests that anthesis stage of the late sown wheat facing high temperature stress is the most responsive stage for the foliar spray of the $\mathrm{KNO}_{3}$ with higher dose if we want to improve yield (Das and Sarkar, 1981; Sakar and Bandopadhyay, 1991). The maximum responsiveness of anthesis stage of wheat towards foliar spray of $\mathrm{KNO}_{3}$ may be attributed to high sensitivity of this stage against elevated temperature $\left(30 / 20^{\circ} \mathrm{C}\right.$, day/night) for 3 days (Saini and Aspinall, 1982). However, if we want to maximize the yield repeated spray at lower concentration is desirable both at booting and anthesis (Fig. 1 and Table 1).

The simple reason is that repeated spray ensures high insurance against yield loss if staggered spells of high temperature stress occurs during pre-anthesis stage (microsporogenesis) of a crop season which causes poor pollen viability, fewer pollen grains and ultimately leads to lower seed set in cereals like wheat and rice (Prasad et al., 2008). Sakar and Tripathy (1994) also found more or less same trend in case of $\mathrm{CaCl}_{2}$ whereby repeated spray of low dose $\mathrm{CaCl}_{2}$ at booting and anthesis gives higher yield however, maximum responsiveness of yield was found when spraying was done at higher concentration during anthesis stage.

\section{Economics of different treatments}

The highest gross return was recorded from variety DBW-14 (Rs. 47,960 ha ${ }^{-1}$ ) which was 14.28\% higher over variety K-307(Rs. 41967 $\left.\mathrm{ha}^{-1}\right)$. Among subplots, $\mathrm{M}_{4}$ treatment with the foliar spray of $\mathrm{KNO}_{3} @ 1 \%$ at booting stage obtain the highest gross return (Rs. 51,744 $\mathrm{ha}^{-1}$ ) which was $17.28 \%$ higher over $\mathrm{M}_{1}$ (Rs. $43005 \mathrm{ha}^{-1}$ ) treatment and it was $16.48 \%$ higher over $\mathrm{M}_{7}$ treatment in variety DBW-14. In variety $\mathrm{K}-307$, highest gross return obtained in $\mathrm{M}_{7}$ treatment (Rs. $44420 \mathrm{ha}^{-1}$ ) with the foliar spray of $\mathrm{CaCl}_{2}(0.1 \%)$ @ both at booting and anthesis stage which is $6.03 \%$ higher over $\mathrm{M}_{1}$ treatment followed by $\mathrm{M}_{4}$ and $\mathrm{M}_{13}$ treatments. Over all highest gross return obtained in $\mathrm{M}_{4}$ treatment (Rs.47733 ha ${ }^{-1}$ ) which was about $11 \%$ higher over $\mathrm{M}_{1}$ (no spray) treatments followed by $\mathrm{M}_{7}$ and $\mathrm{M}_{6}$ treatments. 
The net return was highest in variety DBW-14 (Rs. $20328 \mathrm{ha}^{-1}$ ) which was about $42 \%$ higher over the variety K-307 (Rs. $14308 \mathrm{ha}^{-1}$ ). In sub plot, $\mathrm{M}_{4}$ treatment obtained the highest net return (Rs. 24439 ha $^{-1}$ ) which was $33 \%$ higher over $\mathrm{M}_{1}$ treatment followed by $\mathrm{M}_{3}$ and $\mathrm{M}_{6}$ respectively. In variety $\mathrm{K}-307$, highest net return obtained in $\mathrm{M}_{14}$ treatment (Rs.16638 $\mathrm{ha}^{-1}$ ) which was about $3 \%$ higher overM treatment.

Overall average net return was obtained in $\mathrm{M}_{4}$ treatment (Rs.20428 ha $^{-1}$ ) which was about $18 \%$ higher compare to $\mathrm{M}_{1}$ (no spray) treatment followed by $\mathrm{M}_{3}$ and $\mathrm{M}_{6}$ treatments. The $\mathrm{B}$ : $\mathrm{C}$ ratio was highest in variety $\mathrm{DBW}$ 14 (1.75) which was about $14 \%$ higher compare to the variety K-307 (1.57). In subplot treatment, $\mathrm{M}_{4}$ and $\mathrm{M}_{3}$ obtain the highest B: C ratio (1.90) which was about $11 \%$ higher compared to $M_{1}$ (no spray).

Overall the highest B: $\mathrm{C}$ ratio was recorded in $\mathrm{M}_{4}$ and $\mathrm{M}_{3}$ treatment which was about $5 \%$ higher compare to $\mathrm{M}_{1}$ (no spray) treatment. High temperature can affect metabolic process and ultimately reduce the quantity and quality of output. Spray of above compounds provides more yield even in high temperature stress condition and by more yield we get increased returns, which goes loss due to high temperature.

Rice-wheat system is predominant system of cropping in Indo-Gangetic regions of Bihar and Uttar Pradesh. Long duration rice varieties take more time to mature and delayed sowing of wheat after rice in this region. Due to late sowing of wheat, reproductive stage of the crop which is considered to be the most sensitive to elevated temperature, coincides with the period of high temperature spells, when mean atmospheric temperature rises beyond $20^{\circ} \mathrm{C}$. This imposes stress to the crop during its anthesis to grain filling period. As a result, current photosynthesis gets hampered; resulting in poor translocation of assimilates to the developing grains resulting, lower the yield of wheat.

Based over one-year experimentation, it may be concluded that foliar spray of $\mathrm{KNO}_{3} @ 0.5$ per cent followed by $\mathrm{CaCl}_{2} @ 0.1$ per cent both at booting and anthesis stage should be applied on short duration wheat variety likeDBW 14for achieving maximum grain yield and economic return under irrigated late sown condition.

These compounds play beneficial role by increasing stomatal movement, protein synthesis, enzyme activation, water balance as well as maintain chlorophyll (photosynthetic ability) in leaves against high temperature loss.

\section{References}

Agboma, P.C., Jones. M.G.K., Peltonen-Sainio. P., Rita, H. and Pehu, E. 1997. Exogenous glycinebetaine enhances grain yield of maize, sorghum and wheat grown under two supplementary watering regimes. Journal of Agronomy and Crop Science, 178: 29-37.

Ainsworth, E.A. and Ort, D.R. 2010. How do we improve crop production in a warming world? Plant Physiology, 154:526-530.

Al-Khatib. K. and Paulsen, G.M. 1999. Photosynthesis and productivity during high temperature stress of wheat genotypes from major world regions. Crop Science, 30:1127-1132

Anjum, F., Wahid, A., Javed, F. and Arshad, M. 2008. Influence of foliar applied thiourea on flag leaf gas exchange and yield parameters of bread wheat (Triticum aestivum) cultivars under salinity and heat stresses. International Journal of Agriculture and Biology, 10(6):619-626.

Ashraf, M., Athar, H.R., Harris, P.J.C., Kwon, T.R. 2007. Some prospective strategies 
for improving crop salt tolerance. Advance in Agronomy, 97:45-110.

Bita, C.E. and Gerats, T. 2013. Plant tolerance to high temperature in a changing environment: scientific fundamentals and production of heat stress-tolerant crops. Frontiers in Plant Sciences, 4:273.

Borril1, P., Fahy, B., Smith, A.M. and Uauy, C. 2015. http://www.ncbi.nlm.nih.gov/ pmc/articles/PMC4524614/pdf/pone.0134 947.pdf.

Corbellini, M., Carnevar, M.G., Mazza, L., Ciaffi, M., Lafiandra, E. and Borghi, B. 1997. Effect of the duration and intensity of heat shock during grain filling on dry matter and protein accumulation, technological quality and protein composition in bread wheat and durum wheat. Australian Journal of Plant Physiology, 24:245-250.

Das, S. and Sarkar, A.K. 1981. Effect of postflowering foliar spray of potassium nitrate solution on grain filling and yield of rice and wheat. Indian Agriculture, 25:267273.

Dias, A. and Lidon, F. 2009. Evaluation of grain filling rate and duration in bread and durum wheat, under heat stress after anthesis. Journal of Agronomy and Crop Science, 195: 137-147.

Egilla, J.N., Jr, D.F.T., Drew, M.C. 2001. Effect of potassium on drought resistance of Hibiscus rosasinensis cv. Leprechaun: Plant growth, leaf macro- and micronutrient content and root longevity. Plant and soil, 229(2):213-224.

Fischer, G., Shah, M., Tubiello, F.N. and Velhuizen, H. 2005. Socio-economic and climate change impacts on agriculture: an integrated assessment. Philolophycal. Transactions of the royal society, 29:2067-2083.

Hassanein, R.A., Khalil, S.I., El-Bassiouny, H.M.S., Mostafa, H.A.M., El-Khawas, S.A. and Abd El-Monem, A.A. 2008. Protective role of exogenous arginine or putrescine treatments on heat shocked wheat plant. In: 1st International Conference on Biological and
Environmental Sciences, Hurghada (Egypt),

Hay, R.K.M. and Walker, A.J. 1989. An introduction to the physiology of crop yield. Longman Scientific and Technical, New York, 292.

IFPRI (International food policy research institute), (2011).

IPCC (2012) Managing the Risks of Extreme Events and Disasters to Advance Climate Change Adaptation Cambridge Cambridge University Press, UK.

IPCC (Intergovernmental Panel on Climate Change) 2007. Intergovernmental Panel on Climate Change fourth assessment report: Climate change.

Jiang, Y. and Huang, B. 2001. Drought and heat injury to two cool-season turf grasses in relation to antioxidant metabolism and lipid peroxidation. Crop Science, 41:436442.

Jiang, Y. and Huang, B. 2001. Drought and heat injury to two cool-season turf grasses in relation to antioxidant metabolism and lipid peroxidation. Crop Science, 41:436442.

Kolupaev, Y.E., Akinina, G.E. and Mokrousov, A.V. 2005. Induction of Heat Tolerance in Wheat Coleoptiles by Calcium Ions and Its Relation to Oxidative Stress. Russian Journal of Plant Physiology, 52(2):199-204.

Lobell, D.B., Ortiz-Monasterio, I. J., Asner, G.P., Matson, P.A., Naylor, R.L. and Falcon, W. P. 2005. Analysis of wheat yield and climatic trends in Mexico. Field Crops Research, 94:250-256.

Marschner, H. 1995. Mineral nutrition of higher plants, 2nd ed. Academic Press, London. Misra, A.N., Murum. N., Singh, P. and Mirsa, M. (1997). Growth and proline accumulation in mung bean seedling as affected by $\mathrm{NaCl}$. Biologica Plantarum, 38: 531-536.

Porter, J.R. and Gawith, M. 1999. Temperatures and the growth and development of wheat: a review. European Journal of Agronomy, 10:23-36. 
Prasad, P.V.V., Pisipati, S.R., Ristic, Z., Bukovnik, U. and Fritz, A.K. 2008a. Impact of night time temperature on physiology and growth of spring wheat. Crop Science, 48:2372-2380.

Prasad, R. 2005. Rice-wheat cropping system. Advance in agronomy, 86:255-339.

Rhodes, D. and Hanson, A. D. 1993. Quaternary ammonium and tertiary sulfonium compounds in higher plants. Annual review of plant physiology and plant molecular biology, 44:357-384.

Saini, H. S. and Aspinall, D. 1982. Abnormal sporogenesis in wheat (Triticum aestivum L.) induced by short periods of high temperature. Annual Botany, 49:835-846.

Sarkar, A.K. and Bandyopadhyay, S.K. 1991. Response of wheat cultivars to post flowering foliar application of potassium nitrate solution. Indian Agriculture, 35:269-272.

Sarkar, A.K. and Tripathy, S.K. 1994. Effect of nitrate and its counter ions applied as post- flowering foliar spray on grain filling and yield of wheat. Indian Agriculture, 38:69-73.

Shah, N. and Paulsen, G. 2003. Interaction of drought and high temperature on photosynthesis and grain-filling of wheat. Plant and Soil, 257:219-226.

Singh, A., Singh, D., Kang, J.S. and Aggarwal, N. 2011. Management practices to mitigate the impact of high temperature on wheat. The Institute of integrative omics and applied biotechnology, 2(7):11-22.

Stone, P.J. and Nicolas, M.E. 1994. Wheat cultivars vary widely in their responses of grain yield and quality to short periods of post anthesis heat stress. Australian Journal of Plant Physiology, 21: 887900.

Stone, P.J. and Nicolas, M.E. 1995. A survey of the effects of high-temperature during grain filling on yield and quality of 75 wheat cultivars. Australian. Journal of Agricultural Research, 46:475-492.

Tan, W., Meng, Q.W., Brestic, M., Olsovska, K., Yang, X. (2011). Photosynthesis is improved by exogenous calcium in heatstressed tobacco plants. Journal of Plant Physiology, 168: 2063-2071.

Tewolde, H., Fernandez, C. J. and Erickson, C. A. 2006. Wheat Cultivars Adapted to Post-Heading High Temperature Stress. Journal of Agronomy and Crop Science 192, 111-120.

Wang, Y., Yu, Q.Y., Tang, X.X. and Wang, L.L. 2009. Calcium pre-treatment increases thermo tolerance of Laminaria japonica sporophytes. Progressive Natural Science; 19: 435-442.

Wardlaw, I. F., Blumenthal, C., Larroque, O. and Wrigley, C.W. 2002. Contrasting effects of chronic heat stress and heat shock on kernel weight and flour quality in wheat. Functional Plant Biology, 29: 25-34.

Xu, Q., Paulsen, A.Q., Guikema, J.A., and Paulsen, G.M. 1995. Functional and ultrastructural injury to photosynthesis in wheat by high temperature during maturation. Environment Experimental Botany, 35: 43-54.

\section{How to cite this article:}

Asheesh Chaurasiya, Durgesh Singh, Swaraj Kumar Dutta, Shiv Bahadur and Santosh Kumar Dubey. 2018. Effect of Synthetic Compounds on Performance of Wheat under High Temperature Stress Condition. Int.J.Curr.Microbiol.App.Sci. 7(05): 3543-3554.

doi: https://doi.org/10.20546/ijcmas.2018.705.409 